\title{
Religious law disciplines and formation of general cultural competencies in students
}

\author{
Lyubava Rostislavovna Romanovskaya ${ }^{11}$, Natalya Vladimirovna Evdeeva ${ }^{2}$, Irina \\ Anatolyevna Kiseleva ${ }^{3}$, Sergey Vladimirovich Ostroumov ${ }^{2}$, and Vladislav Vladimirovich \\ Gruzdev $^{2}$ \\ ${ }^{1}$ Lobachevsky State University of Nizhny Novgorod, Faculty of Law, Department of Constitutional \\ and Administrative Law, Nizhny Novgorod, Russia \\ ${ }^{2}$ Lobachevsky State University of Nizhny Novgorod, Faculty of Law, Department of Theory and \\ History of the State and Law, Nizhny Novgorod, Russia \\ ${ }^{3}$ Lobachevsky State University of Nizhny Novgorod, Faculty of Law, Department of Criminal Law \\ and Procedure, Nizhny Novgorod, Russia
}

\begin{abstract}
The purpose of the study is to substantiate the fundamental correlation between the spiritual health of the society and civil peace and harmony in the country, as well as to analyse the efficiency of teaching religious law disciplines in the context of the formation of major general cultural competencies in law students. The methodological basis of the study was represented by the civilisational approach, the dialectical method, general logical methods as well as the integrative approach that made it possible to combine legal and religious aspects within the framework of special interdisciplinary academic disciplines. Observation and interviewing techniques were also used. It was found out in the course of the study that one of the most important components of countering external and internal threats to the national security is one's spiritual and moral foundations that must be formed in the student environment in the process of educational work, in particular, within the framework of teaching special religious law disciplines. They should be conceptually based on the postulate that religion, culture and law constitute a single civilisational aggregate characterised by complex internal interrelations and patterns of development. Students should realise that the knowledge of these laws makes it possible to understand that, despite the difference in civilisational models, there exists a fundamental affinity in the basic principles of different religious confessions and basic cultural aspirations of various nations. The novelty of the work is accounted for by the conclusion that the study of spiritual and moral foundations of the existing religious and non-religious spiritual doctrines, as well as the fundamental links between religion and law, contributes to the formation of basic general cultural competencies in students, as well as positive value attitudes.
\end{abstract}

Keywords: spiritual and moral crisis, traditional values, legal education, religion and law, interfaith dialogue

${ }^{1}$ Corresponding author: elza_r@mail.ru 


\section{Introduction}

The relevance of the research is accounted for by the importance of the issues involving the formation of spiritual and moral potential of young people of Russia in the conditions of moral and ideological crisis, devaluation of moral values, social anomie. The socio-political discourse forms a demand for innovative forms and methods of the individual's spiritual/moral education, in particular, in higher education. One of the key strategic planning documents that set the development of our country for the coming years is the National security strategy of the Russian Federation (approved by Presidential Decree No. 683 as of 31.12.2015) which outlines, as one of the core threats in the sphere of culture, erosion of the traditional Russian spiritual and moral values and weakening of the unity of the multinational Russian Federation through external cultural and informational expansion (clause 79 of the Strategy). The threats in the given context are deemed as external; however, this approach has constraints since they may have an internal source. Countering only external threats can lead to self-isolation and confrontation with other countries perceived as a "moral" aggressor. The authors do not dispute the fact that spiritual/moral expansion is one of the most efficient methods of geopolitical expansion used by the developed countries and that it is necessary to oppose it in order to ensure Russia's national security. At the same time, such "expansion" should be practiced by our country as well - to spread own traditional values, culture, to preserve and extend the use of the Russian language as a language of interethnic communication. As Professor Tonkonogov notes convincingly, "the status of a country depends not only on the extent of development and independence of the economy and military sphere, but also on the presence of progressively evolving and expanding national spiritual space" [1, p. 142]. Spiritual "expansion" should not be regarded as a benefit (if undertaken on our part) or evil (if enforced by the others). This is a factor to be taken into account for maintaining the national security, and a method to be used in solving geopolitical problems.

Russia implements the cultural and national policy aimed at strengthening and augmenting the traditional Russian spiritual and moral values, while ensuring national, religious and racial tolerance, fostering mutual respect for the peoples of Russia. The Strategy highlights the traditional values, in particular, the priority of the spiritual over the material, creative work, allegiance to the Fatherland, morality and ethics, humanism, benevolence, justice, mutual help, collectivism, historical unity of the peoples of Russia.

The authors agree with Dezhnev and Novikova in the postulate that, when analysing the concept of "traditional values", it is not enough just to name them: "it is necessary to identify their essence, interrelation and interdependence, determination by natural and geographical environment, as well as the original development of the Russian society, statehood and the entire history of our country" [2, p. 72]. It should be noted that even official documents can interpret this term in different ways. For instance, the Strategy for development of education in the Russian Federation for the period until 2025 (approved by the Enactment of the Russian Federation Government No. 996-r as of May 29, 2015) includes the following in the system of spiritual and moral values: philanthropy, justice, honour, conscience, personal dignity, faith in goodness and urge to sustain moral obligations to oneself, one's family and the Fatherland. The task of strengthening and augmenting these traditional values is also a prerogative of higher educational establishments, which confirms the social importance of the spiritual- and religious-law subject domain in the educational process.

\section{$2 \quad$ Materials and methods}

The methodological basis of the given research is represented by the civilisational approach, as well as the dialectical method which made it possible to trace the internal relationship 
between the phenomena under consideration. The above was supplemented and concretised by the methods of systemic analysis, synthesis, abstraction, generalisation, integrative approach, sociological methods of monitoring the educational process, interviewing (conversations with students and teachers). The statutory framework underlying the research is represented by the acts of the Russian legislation in force, in particular, Federal Law No. 273-FZ as of 29.12.2012 "On education in the Russian Federation"; National security strategy of the Russian Federation; Strategy for development of education in the Russian Federation for the period until 2025; Order of the Russian Federation Ministry of Education and Science No. 1511 as of 01.12.2016 "On approval of the federal state educational standard of higher education in the training profile 40.03.01 Jurisprudence (baccalaureate level)". The analysis of statutory acts involved private-law methods (law interpretation methods, technical-law method).

\section{$3 \quad$ Results}

The results of the study showed that university students have a strong interest in spiritual and religious law issues. This is largely accounted for by the so-called "crisis of youthhood", when young people capitally face the existential crisis for the first time - the raison d'etre crisis. It is at that period that the questions about the life purpose in general and the meaning of one's own life are actualised. Another important reason for this interest is the multinational and multi-religious composition of the student body. The mission of the higher school is to instill the skills of good-neighbourly relations and positive intercultural and interreligious communication in students, to integrate religion, culture and law into a single civilisational complex, to show the affinity of major cultural aspirations of different nations and the commonness of the basic principles of different religious confessions.

In the course "Religion and Law" taught at the Faculty of Law of UNN (Lobachevsky State University of Nizhny Novgorod), all world, national, ancient and new religious confessions are studied, with an accent on religious traditions that advocate respect and tolerance, that are open to a joint search for truth and sincere interfaith dialogue. Within the framework of this discipline, the connection between different confessions and law is revealed: Christianity and law, Islamic madhhabs and Shariah, Hinduism and dharma law, Judaism and Old Testament legal norms; the features of regulatory prescriptions of Zoroastrianism, Buddhism, Mahayana and Hinayana, Baha'i faith, Confucianism and Legalism and other non-religious, though spiritual, doctrines [3].

The study of subjects related to Buddhism, Taoism, moral and philosophical teachings of various branches of Buddhism, the practices of personal self-improvement, spiritual development and self-cognition are of interest for the students who do not profess any religion but feel the need for spiritual development. As to "gnostics" who do not accept any religious forms explaining existence, but at the same time do not accept the extra-moral paradigm of life, Buddhist philosophy satisfies their intellectual and spiritual needs, gives a clear understanding of the individual's inner path.

The authors believe that the study of Orthodoxy and Christianity in general, of the basic Christian commandments, the concepts of sin and virtue should be an important component of spiritual education and advancement. The main emphasis in this schooling should be placed not on the existing confessional differences in interpretation of Christ's teachings, but on the common foundations that allow for maintaining and developing a dialogue within the Christian world.

It was also found out that one of the modern threats is the strengthened influence of fundamentalists of different persuasions, their impact on young people who do not yet have deeply-rooted religious, moral and legal guidelines. They incline young people to illegal actions, make them join various terrorist organisations under the guise of fighting for Islam. 
In these conditions, it becomes quite obvious that the study of classical peace-loving Islam is a matter of paramount importance in terms of educational, cultural and political framework.

A number of general cultural, general professional and professional competencies to be formed in a university graduate are distinguished within the framework of the competence approach. According to the Federal state educational standard of higher education in the training profile 40.03.01 Jurisprudence (baccalaureate level), the general cultural competencies include: the ability to apply the foundations of philosophical knowledge for developing a proper worldview (OK-1); the ability to work in a team, while tolerantly perceiving social, ethnic, confessional and cultural differences (OK-6). The disciplines "Religion and law", "Russian religious philosophy" undoubtedly make a serious contribution in the formation of these competencies. The authors note that the Federal state educational standard mentions a general professional competence "the ability to work for the benefit of the society and the state (OPK-2)" among the others. However, the formation of such competence is impossible without the disciplines (modules) that convey a powerful pedagogical (not just educational) potential.

\section{Discussion}

The rejection of the communist ideology in the late $80 \mathrm{~s}$ of the 20th century entailed the denial of pedagogical function of the educational system. In the conditions of ideological pluralism and deideologisation of education, this function, according to the reformers, was to be taken over by the civil society. However, this approach did not justify itself. In the first decade of the 21 st century, the public discourse generated a request to work out the ideological foundations of the state policy and to strengthen the educational component of education. The society gained understanding of the fact that the formation of moral personality is the mission of not only the family, of preschool and school education, but also of higher educational establishments. The specialists sought by the society must be competent in various fields, but, in addition, they should firmly adhere to moral and value-oriented priorities in their professional activity.

The relevance of the problems of spiritual/moral education of young people within the framework of the higher education system is confirmed by the studies undertaken mainly by representatives of the humanities (pedagogues, sociologists, etc.): in particular, [4-11], etc. However, a number of studies have also been published, aimed at assessing the potential of mathematics- and other natural-science departments of universities in terms of contribution to the educational process [12-13]. Gafiatulina and Zagirova raise the issue of interrelation between the formation of traditional spiritual and moral values of young people and maintaining the security of the society; they note that the traditional religious institutions may become an important element of the mechanism for countering ideological threats [14]. Among the scholars the authors are consistent with, in assessing the importance of integration of scientific and religious knowledge about the world and man, state and law, the material and the spiritual, the secular and the sacred, in terms of the attitudinal framework of the Russian higher education, are Belkin, Gutsu, Kontorovich [15], Mikhalkin [16].

The problem of devaluation of the traditional moral values in the context of globalisation and the growing influence of the western civilisation on differing ideologies exists not only in the Russian society. The scholars from different countries note the importance of the formation of students' (young people's) moral values. For instance, Dr. Shailaj Kumar Shrivastava (Patna, India) notes that morally oriented education can play an important role in fostering the sense of affinity and solidarity between different sectors of the Indian society. He views value-oriented education as an integral part of the educational system as a whole [17]. Leslie Lo, Professor of Hong Kong University (Hong Kong, China), emphasises the importance of finding new, alternative approaches to moral education in the networked world 
(the world of rapid development of information technologies, cyber reality). She argues that the fear- and control-based approach does not meet the requirements of the information era [18].

\section{Conclusion}

Religious law disciplines not only have a significant educational potential, but also make it possible to solve an extremely important task - spiritual/moral education of students. They involve the study of socially important subject areas, the issues of self-awareness and selfimprovement that need discussion intended to promote the development of skills of positive intercultural communication in the present and future professional, public and private life of students, to contribute to their spiritual advancement. In addition, they contribute to the development of students' respectful attitude to different religious and cultural traditions, to people and communities of different civilisational types.

The practical significance of the research lies in proposing specific forms and methods intended to enhance the pedagogical component in the educational process. The research results can be used in the educational process, in particular, in the formation of elective disciplines under the bachelor and master degree programmes.

\section{References}

1. A.V. Tonkonogov, Socio-Humanitarian Knowledge, 2, 141-153 (2014). Accessed on: June 12, 2020. [Online]. Available:

$\mathrm{http}: / /$ тонконогов.pф/files/Духовная\%20экспансия\%20Тонконогов.doc

2. V.N. Dezhnev, O.V. Novikova, Bulletin of Shadrinsk State Pedagogical University, 4(28), 27-29 (2015). Accessed on: June 12, 2020. [Online]. Available: https://cyberleninka.ru/article/v/traditsionnye-tsennosti-k-opredeleniyu-ponyatiya

3. V.P. Salnikov, M.V. Salnikov, V.B. Romanovskaya, L.R. Romanovskaya, Law-Bound State: Theory and Practice, 3(41), 16-22 (2015). Accessed on: August 16, 2020. [Online]. Available: https://elibrary.ru/item.asp?id=24289265

4. L.S. Burdyakova, Proceedings of Moscow University for the Humanities, 1, 13-22 (2017). Accessed on: June 12, 2020. [Online]. Available: https://cyberleninka.ru/article/n/duhovno-nravstvennoe-vospitanie-molodezhi-kakpedagogicheskoe-yavlenie. http://dx.doi.org/10.17805/trudy.2017.1.2

5. V.A. Belyaeva, A.A. Petrenko, The humanities scholar: topical issues of science and education, 2(22), 1-14 (2013). Accessed on: June 25, 2020. [Online]. Available: http://elibrary.ru/item.asp?id=20655357

6. N.Kh. Gafiatulina, Bulletin of Institute of History, Archeology and Ethnology of the Peoples of the Far-East, 1(49), 134-144 (2017). Accessed on: June 25, 2020. [Online]. Available: https://cyberleninka.ru/article/v/duhovno-nravstvennaya-bezopasnostrossiyskoy-molodezhi-sotsiologicheskiy-analiz-osnovnyh-ugroz

7. E.M. Zezeka, Bulletin of Moscow State University of Culture and Arts, 4(42), 147-151 (2011). Accessed on: June 26, 2020. [Online]. Available: https://cyberleninka.ru/article/v/suschnost-i-spetsifika-protsessa-duhovnonravstvennogo-vospitaniya-molodezhi-v-uchrezhdeniyah-kultury

8. M.E. Merezhko, The society: philosophy, history, culture, 3-4, 118-120 (2011). Accessed on: June 26, 2020. [Online]. Available: 
https://cyberleninka.ru/article/v/analiz-problem-duhovno-nravstvennogovospitaniya-studentov-vuzov

9. M.A. Mefodieva, Transactions of Kazan State Academy of Veterinary Medicine named after N.E. Bauman, 3, 219-222 (2014). Accessed on: June 26, 2020. [Online]. Available: https://cyberleninka.ru/article/n/duhovno-nravstvennoe-vospitaniestudentov-v-usloviyah-globalizatsii

10. V.P. Rubaeva, Bulletin of Irkutsk National Research Technical University, 3(74), 218221 (2013). Accessed on: June 26, 2020. [Online]. Available:

https://cyberleninka.ru/article/n/voprosy-formirovaniya-nravstvenno-tsennostnyhprioritetov-studentov-v-kontekste-innovatsionnoy-deyatelnosti-uchrezhdeniyvysshego

11. N.N. Shatokhina, Transactions. Electronic Academic Journal of Kursk State University, 3(19) (2011). Accessed on: June 29, 2020. [Online]. Available: http:// www.scientific-notes.ru/pdf/020-023.pdf

12. S.N. Dvoryatkina, M.A. Mkrtchyan, S.A. Rozanova, Integration of Education, 22(2), 353-368 (2018). http://dx.doi.org/10.15507/1991-9468.091.022.201802.353-368

13. S.N. Dvoryatkina, Bulletin of Moscow State Regional University. Series: Pedagogy, 4, 79-84 (2009). Accessed on: July 1, 2020. [Online]. Available: http://vestnikmgou.ru/Articles/Doc/1990

14. N. Kh. Gafiatulina, E.M. Zagirova, Bulletin of Institute of History, Archeology and Ethnology of the Peoples of the Far-East, 2(50), 143-157 (2017). Accessed on: July 15, 2020. [Online]. Available: https://cyberleninka.ru/article/n/sistema-tsennosteyrossiyskoy-molodezhi-v-kontekste-obespecheniya-duhovno-nravstvennoybezopasnosti-obschestva

15. A.I. Belkin, V.G. Gutsu, S.N. Kontorovich, Integration of Education, 20(1), 112-124 (2016). http://dx.doi.org/10.15507/1991-9468.082.020.201601.112-124

16. V.S. Mikhalkin, Integration of Education, 19(3), 108-114 (2015). http://dx.doi.org/10.15507/Inted.080.019.201503.108

17. S.K. Shrivastava, International Journal of Research in Social Sciences, 7(6), 103-108 (2017). Accessed on: July 24, 2020. [Online]. Available: https://www.researchgate.net/publication/317279040_PROMOTION_OF_MORAL_VALUES_THROUGH_EDUCATION

18. N.K. Leslie Lo, US-China Education Review, 3(3) (Serial No. 16) (2006). Accessed on: August 10, 2020. [Online]. Available:

https://files.eric.ed.gov/fulltext/ED497369.pdf 